\title{
Diagnostic ability of SPECT-CT of Parathyroid Gland in correlation with different Biochemical Markers, BMD and USG of neck -Single Institute based Experience
}

\author{
Samira Sharmin 1 , Jasmine Ara Haque ${ }^{2}$, Hosne Ara Rahman ${ }_{3}^{1}$, Jamiul Hossian 1 , AzmalKabir Sarker , Farida Yesmin , Md. \\ Monir Uddin ${ }^{3}$ and Syed Muhammad Baqui Billah 4 \\ 1 Institute of Nuclear Medicine and Allied Sciences,SSMCH, Mitford, Dhaka, \\ National Institute of Nuclear Medicine and Allied Sciences, BSMMU, Dhaka \\ ${ }_{4}^{3}$ Comilla Medical College \\ Sulaiman Al Rajhi Colleges, Al Qassim, KSA
}

Correspondence Address: Dr. Samira Sharmin,Senior Medical Officer, Institute of Nuclear Medicine and Allied Sciences, Sir Salimullah Medical College Hospital Campus, Mitford, Dhaka-3100. Email- samira958@gmail.com

\begin{abstract}
Objective: Detection of parathyroid adenoma or hyperplasia/ carcinoma by imaging is very challenging. The objective of this study was to assess

the imaging findings of Single-Photon Emission Computed Tomography/Computed Tomography (SPECT/CT) in neck and thorax of patients and correlation with parathyroid hormone (PTH), Serum calcium, Inorganic phosphate(IP), Bone mineral density ( BMD) and also with neck ultrasonography (USG of neck).

Material \& Methods: A total 75 study subjects were included in this retrospective study conducted from January 2011 to November 2018 in the Institute of Nuclear Medicine and Allied Sciences (INMAS), SSMCH, Mitford, Dhaka. All the patients came in this institute for parathyroid SPECT-CT were included for this study. SPECT-CT findings were compared with USG of neck, PTH serum calcium, inorganic phosphate (IP) level and BMD findings.

Results: In this study $29(38 \%)$ were male and $46(62 \%)$ were female. Mean PTH was $469 \pm 667 \mathrm{pg} / \mathrm{ml}$, range $20-3110 \mathrm{pg} / \mathrm{ml}$, mean serum calcium $9.8 \pm 1.5 \mathrm{mg} / \mathrm{dl}$ with range $6.20-14.30 \mathrm{mg} / \mathrm{dl}$, mean $I P 3.0 \pm 0.8 \mathrm{mg} / \mathrm{dl}$ with range of $1.7-4 \mathrm{mg} / \mathrm{dl}$. SPECT-CT positive patients were $32(42.7 \%)$ and negative patients were $43(53.3 \%)$. USG of neck positive patients were 21 $(28 \%)$ and negative patients were $54(72 \%)$.The PTH $(r=0.53, p=0.0)$ serum Calcium $(\mathrm{r}=0.66, \mathrm{p}=0.0)$ positively correlate with SPECT-CT positive patients and negatively with IP level $(r=-0.177, p>0.05)$. Among 75 the patients, 44 patients had BMD report. $28(63.6 \%)$ patients had SPECT -CT negative findings and $16(36.4 \%)$ patients with positive SPECT-CT findings with $P$ value $<\mathbf{0 . 0 5}$.

Conclusion: This study showed the positivity of SPECT-CT parathyroid imaging positively correlate with PTH, serum calcium and inversely correlate with IP. This study also showed that SPECTCT is better than USG of neck not only localization of parathyroid gland in normal anatomical position but also in ectopic position. Key words: SPECT-CT, PTH, Serum calcium, IP, BMD

Bangladesh J. Nucl. Med. Vol. 21 No. 2 July 2018

Doi: https://doi.org/10.3329/bjnm.v21i2.40325
\end{abstract}

\section{INTRODUCTION}

Parathyroid gland disorder is a common endocrine disorder (1). SPECT/CT imaging modality is very much popular and inexpensive methodfor detection of parathyroid gland abnormality within few decades. The elevated Parathormane (PTH) level results in hypercalcemia and hypophosphatemia with associated medical comorbidities including calculus formation, bone and abdominal pain, polyuria, and renal impairment (2). The aim of this study was to findout the relationship between the diagnostic ability of fused (SPECT/CT) images in localization of parathyroid gland disorder in relation with different biochemical markers along with ultrasonogram (USG) of neck.

\section{PATIENTS AND METHODS}

This retrospective study was conducted in the Institute of Nuclear Medicine and Allied Sciences, SSMCH, Mitford, Dhaka from January 2011 to November 2018. Symbia SPECT-CT machine was used for parathyroid imaging. Parathyroid SPECT scan was done both 20 minutes and 02 hours after administration of $20 \mathrm{~m} \mathrm{Ci}$ MIBI intravenously. Images were reconstructed in sagittal, coronal and transverse planes. Then image was interpret as positive or negative to detect parathyroid adenoma or hyperplasia. Patient's medical records were checked for PTH, serum calcium, IP level and BMD results. The biological reference interval for PTH- 7-53 $\mathrm{pg} / \mathrm{ml}$, serum calcium level $8.20-10.20 \mathrm{mg} / \mathrm{dl}$, IP level2.50-5 mg/dl. BMD scored as normal (T- $\geq$ score -1$)$, 
osteopenia (T-score $<-1$ and $>-2.5$ ) and osteoporosis (T-score $\leq-2.5)$ based on T-score.

\section{RESULTS}

A Total 75 patients were enrolled for this study, 29 $(38.66 \%)$ were male and 43(61.34\%) were female.Among 75 patients, 4 (5.3\%) patients had history of recurrent parathyroid adenoma $(\mathrm{H} / \mathrm{O}$ of previous parathyroidectomy) with normal PTH level, 2(2.6\%) patient had parathyroid carcinoma, and 1(1.3\%) was follicular carcinoma of thyroid with raised PTH, 20 (26.7\%) patients had history of renal impairment with nephrolithiasis, $1 \quad(1.3 \%)$ with cholelithiasis and $3(4 \%)$ with history of fracture. Rest of the 44 (58.8\%) patients came with raised PTH level and Serum calcium level or incidental findings during USG of neck.

Mean PTH was $469.58 \pm 667.13 \mathrm{pg} / \mathrm{ml}$ with range 20 $3110 \mathrm{pg} / \mathrm{ml}$, mean serum calcium $11.26 \pm 1.02 \mathrm{mg} / \mathrm{dl}$ with range $9.20-13.30 \mathrm{mg} / \mathrm{dl}$, mean IP $2.8 \pm 0.4 \mathrm{mg} / \mathrm{dl}$ with range of $1.7-3.9 \mathrm{mg} / \mathrm{dl}$.

Regarding distribution of abnormalparathyroid gland in relation with thyroid gland (C5 to D1 vertebrae) this study showed that most of the gland were located $40.6 \%$ (13 out of 32) in inferior to the thyroid gland at the level of C7-D1 vertebrae and $21.8 \%$ (7 out of 32) in ectopic positions.

Table 1: Location of the abnormal parathyroid gland (foci) in SPECT-CT

\begin{tabular}{|l|r|l|r|r|r|r|l|}
\hline $\begin{array}{l}\text { Anatomic } \\
\text { location }\end{array}$ & Superior & $\begin{array}{l}\text { Inferior } \\
\text { with } \\
\text { retrostcrnal } \\
\text { extension }\end{array}$ & Inferior & $\begin{array}{l}\text { Bilateral } \\
\text { Superior/ } \\
\text { Inferior }\end{array}$ & Mid part & Ectopic & Total \\
\hline $\begin{array}{l}\text { Right lobe } \\
\text { of thyroid }\end{array}$ & 3 & 0 & 6 & 2 & 0 & 0 & $11(34.4 \%)$ \\
\hline $\begin{array}{l}\text { Left lobe of } \\
\text { thyroid }\end{array}$ & 2 & 4 & 7 & 0 & 0 & 0 & $13(40.6 \%)$ \\
\hline Ectopic & 0 & 0 & 0 & 0 & 0 & 7 & $7(21.9 \%)$ \\
\hline Mid part & 0 & 0 & 0 & 0 & 1 & 0 & $1(3.1 \%)$ \\
\hline Total & $5(15.6 \%)$ & $4(12.5 \%)$ & $13(40.6 \%$ & $2(6.4 \%)$ & $1(3.1 \%)$ & $7(21.8 \%)$ & $32(100)$ \\
\hline
\end{tabular}

Among SPECT-CT positive patients mean PTH $909.88 \pm 839.2 \mathrm{pg} / \mathrm{ml}$ and negative SPECT-CT patient had mean PTH was $141.90 \pm 82 \mathrm{pg} / \mathrm{ml}$. The test was statistically significant $(\mathrm{P}<0.5)$.

Table 2: Mean \pm SD of PTH, S. Calcium, Inorganic Phosphate (IP) in positive and negative SPECT-CT patients

\begin{tabular}{|l|l|l|l|}
\hline & SPECT-CT & & \\
\hline & Positive & Negative & P value \\
\hline PTH & $909.88 \pm 839 \mathrm{pg} / \mathrm{ml}$ & $141.82 \pm 84 \mathrm{pg} / \mathrm{ml}$ & $<0.00$ \\
\hline S.Ca & $12.04 \pm 0.90 \mathrm{mg} / \mathrm{dl}$ & $10.68 \pm 0.65 \mathrm{mg} / \mathrm{dl}$ & $<0.00$ \\
\hline IP & $2.6 \pm 0.4 \mathrm{mg} / \mathrm{dl}$ & $2.9 \pm 0.4 \mathrm{mg} / \mathrm{dl}$ & $<0.013$ \\
\hline
\end{tabular}

Negative SPECT-CT patients had mean serum calcium was $10.6 \pm 0.65 \mathrm{mg} / \mathrm{dl}$ and positive SPECTCT patients had mean serum calcium level $12.04 \pm 0.9$ $\mathrm{mg} / \mathrm{dl}$. The test was statistically significant $(\mathrm{P}<0.05)$.

Positive SPECT-CT patient had mean IP level was $2.6 \pm 0.4 \mathrm{mg} / \mathrm{dl}$ and negative SPECT-CT patient had mean IP level $2.9 \pm 0.4 \mathrm{mg} / \mathrm{dl}$.The test was statistically significant $(\mathrm{P}<0.05)$.

$32(42.7 \%)$ patients were SPECT-CT positive and 43(57.3\%) patients were SPECT-CT negative. In comparison with USG showed 21 (28\%) were positive and 54 (72\%) were negative.

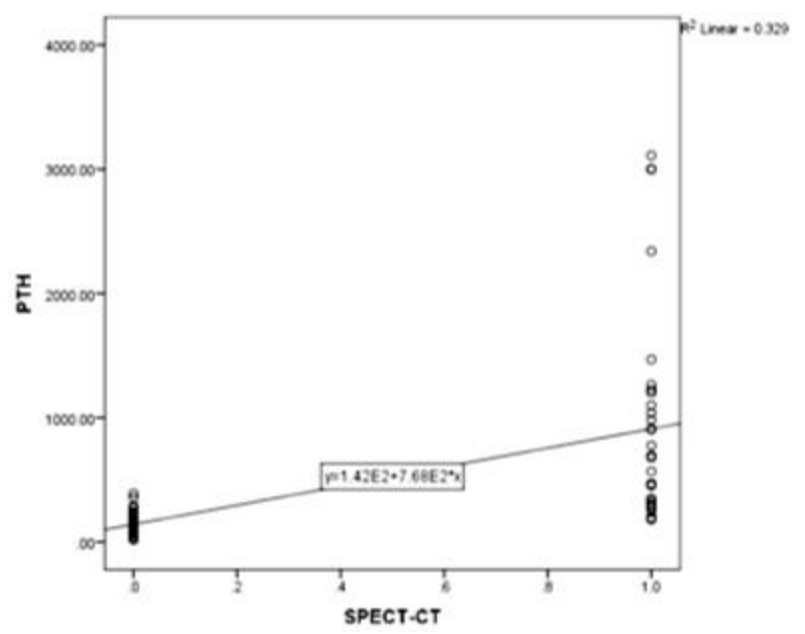

Figure 1: Relationship between PTH and SPECT-

\section{CT of parathyroid.}

The PTH $(r=0.573 \mathrm{p}=0.0)$, s.ca $(\mathrm{r}=0.66, \mathrm{P}=0.0)$ was correlate with the SPECT-CT result butthe IP level $(r=-0.177, p=0.12)$ showed negative relationwith 
SPECT-CT result and the result was not statically significant $(\mathrm{P}>0.05)$.

Among all 75 patients, BMD results were found 44 patients. Those patients who had normal BMD result, PTH was lower than those who had osteoporosis and fracture. Among negative SPECT-CT findings patient's $22(50 \%)$ had normal BMD level, 3(6.8\%) had osteopenia and 2(4.5\%) had osteoporosis with lower PTH level $(<300 \mathrm{pg} / \mathrm{ml})$. Those who had positive SPECT-CT findings showed that 4 (12.5\%) had normal BMD, 5 (11.4\%) had osteopenia, 4 (9\%) had osteoporosis and 3(4\%) with history of fracture with PTH level $>2000 \mathrm{pg} / \mathrm{ml}$.

\section{DISCUSSION}

This study showed that among 75 patients, 43(61.34\%) were female and 29 (38.66\%) were male with mean age of the study people was $39 \pm 14.9$ range 5 to 75 years. This findings were consistent with other studies they also showed that female patients more than male patients. A study conducted by Gayed et al. (2017) showed that among 53 patients with mean age $58.3 \pm 14$ years and female predominance- 44 women (83\%) and 09 (17\%) men (3). Another study conducted by Rahman et al.(2014) foundthat mean age was $41.3 \pm 19.8$ years (range 21-63 years). Female were predominant than male which was 31 $(56.4 \%)$ and 24 (43.6\%) respectively (4).

According to the history of the patients most of them diagnosed incidentally (44.4\%) during USG of neck or nephrolithiasis with renal impairment (28\%). These findings were consistent with other study (2). A study conducted by Ciappuccini et al. (2012). found that among 94 patients SPECT/CT demonstrated a single focus in 56 patients, among them in usual parathyroid sites were $80 \%$ of cases and in unusual sites the remaining $20 \%$ (retrotracheal area, 7\%; intrathyroidal 9\%; mediastinum $4 \%$ ), and double foci in 3 (2).

In this study localization of abnormal parathyroid gland in SPECT-CT single focus in 18(56.2 \%) patients in usual parathyroid sites and $7(21.8 \%)$ in ectopic sites (mediastinum, retrophaengeal, retrotracheal ), double foci were2(6.4\%) and inferior location with retrosternal extension was $4(12.5 \%)$ and intrathyroidal (mid part) was $1(3.1 \%)$. This was consistent with above findings.

This study showed mean PTH was $469.58 \pm 667.13 \mathrm{pg} / \mathrm{ml}$ with range $20-3110 \mathrm{pg} / \mathrm{ml}$, mean serum calcium $11.26 \pm 1.02 \mathrm{mg} / \mathrm{dl}$ with range 9.20 $-13.30 \mathrm{mg} / \mathrm{dl}$, mean IP $2.8 \pm 0.4 \mathrm{mg} / \mathrm{dl}$ with range of 1.7 $-3.9 \mathrm{mg} / \mathrm{dl}$. Other studies also showed the similar findings. Astudy conducted by Sager et al. (2014) that the mean PTH level was $258 \pm 161.5 \mathrm{pg} / \mathrm{mL}$, serum calcium level was $11.26 \pm 0.85 \mathrm{mg} / \mathrm{dL}$ and IP level was $2.56 \pm 0.71 \mathrm{~m} \mathrm{Eq} / \mathrm{L}$ (5). Another study conducted by Ishibashi et al.(1997) found that PTH concentrations ranged from 92-2399 $\mathrm{pg} / \mathrm{ml}$ (mean $777.4 \pm 651.4$ $\mathrm{pg} / \mathrm{ml}$ ), serum calcium from $6.8-15 \mathrm{mg} / \mathrm{ml}$ (mean $10.8 \pm$ $1.6 \mathrm{mg} / \mathrm{ml}$ ) and IP ranged from $1.7-8.6 \mathrm{mg} / \mathrm{ml}$ (mean $4.1 \pm 2.0 \mathrm{mg} / \mathrm{ml})(6)$.

In this study we found that SPECT-CT positive patients mean PTH $909.88 \pm 839.2 \mathrm{pg} / \mathrm{ml}$, serum calcium level $12.04 \pm 0.9$, IP level $2.6 \pm 0.4 \mathrm{mg} / \mathrm{dl}$ and negative SPECT-CT patient had mean PTH was 141.90

$\pm 82 \mathrm{pg} / \mathrm{ml}$, mean serum calcium was $10.6 \pm 0.65$ $\mathrm{mg} / \mathrm{dl}$ and mean IP level $2.9 \pm 0.4 \mathrm{mg} / \mathrm{dl}$. The test was statistically significant $(\mathrm{P}<0.5)$.

Similar results also found Akter et al. (2013) showed that positive scintigraphy patient's PTH level was $938 \pm$ $768.71 \mathrm{pg} / \mathrm{ml}$, serum calcium level11.84 $\pm 1.18 \mathrm{mg} / \mathrm{dl}$ and

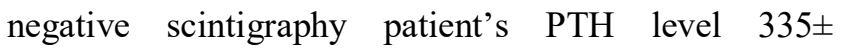
$264.92 \mathrm{pg} / \mathrm{ml}$, serum calciuml $0.63 \pm 1.02 \mathrm{mg} / \mathrm{dl}$ (7).

Another study conducted by Hoang et al. (2018) found the similar findings. They showed that in negative SPECT-CT patients PTH $142.70 \pm 122.26 \mathrm{pg} / \mathrm{ml}$, s.ca $11.10 \pm 0.75$ $\mathrm{mg} / \mathrm{dl}$, IP $2.82 \pm 0.68 \mathrm{mg} / \mathrm{dl}$ and incase of positive SPECTCT patients PTH $190.43 \pm 173.20$ pg $/ \mathrm{ml}$, s.ca $11.27 \pm 0.54$ $\mathrm{mg} / \mathrm{dl}$, IP $2.58 \pm 0.58 \mathrm{mg} / \mathrm{dl}$. These findings were consistent with the present study (8). 
Similar study conducted by Nasreen et al.(2007) also showed that positive scintigraphy patients showed raised PTH level and serum calcium level comparison to negative sintigraphy patients (9).

Now a days most of the institutions performed at least 2 imaging modalities to confirm the presence and location of abnormal parathyroid gland and usually a combination of USG of neck and SPECT-CT $(9,10)$.

This study also revealed that $32(42.7 \%)$ patients were SPECT-CT positive and 43(57.3\%) patients were SPECT-CT negative. In comparison USG shows 21 (28 $\%)$ were positive and $54(72 \%)$ were negative. This findings consistent with study conducted by Nasiriet al.(2012) and Akter et al.(2013) (7,10). Akter et al. (2013) showed that among 36 patients scintigrpahy positive were $29(80.6 \%)$ and negative were $7(19.4 \%)$ on the hand US of neck positive $23(63.9 \%)$ and negative were 13(63.9\%) (7). Ectopic position parathyroid glands could not be identified by USG of neck which is consistent with other studies $(7,9,10,11)$.

The PTH $(r=0.573 \mathrm{p}=0.0)$, serum calcium $(r=0.66$, $\mathrm{P}=0.0$ ) correlate with the SPECT-CT findings but the IP level $(\mathrm{r}=-0.177, \mathrm{p}=0.12)$ showed negative relationwith SPECT-CT result and the result was not statically significant $(\mathrm{P}>0.05)$. This study result was consistent with other studies they showed higher level of PTH, s.ca and low normal IPlevel correlate with positive sintigraphy findings $(4,6)$.

In this study, out of 75 patients, 44 had BMD report. Among them 28 patients were SPECT-CT negative showed 23 had normal BMD, 2 had osteopenia and 3 had osteoporosis. Again SPECT-CT positive patients were 16 in numbers, among them 3 had normal BMD value, 5 had osteopenia and 8 had osteoporosis. This findings was consistent with a study conducted by Hoang et al. 2018 .

\section{CONCLUSION}

This study reveals that positive SPECT-CT findings had positive relationship with $\mathrm{PTH}$, serum calcium, BMD and inverse relationship with IP level. USG of neck is helpful to detect abnormal parathyroid gland but SPECT-CT is superior especially in case of ectopic.

\section{REFERENCES}

1. AlZahrani, Levine MA. Primary hyperparathyroidism. Lancet 1997;349(9060):1233-1238.doi.org/10.1016/s0140-6736(96)06176-4.

2. Ciappuccini R, Morera J, Pascal P, Rame J-P, Heutte N, Aide N, Babin E, ReznikY, and Bardet S. Dual-Phase 99mTc Sestamibi Scintigraphy With Neck and Thorax SPECT/CT in Primary Hyperparathyroidism -A Single-Institution Experience. Clinical

Nuclear Medicine 2012; 223-228. Doi:10.1097/RlU.0b013e31823362e5.

3. GayedI,KarniR,WanD,VargheseJ,WirfelK,Won K and Joseph U. Interpretation of Tc-99m Sestamibi parathyroid SPECT-CT scans made easy for better surgical outcomes in patients with primary hyperparathyroidism. Reports in Medical Imaging. 2017; 101-7. Doi https://doi.org/10.2147/RMI.S11224.

4. RahmanR, HaqueJ, Sharmin S. Sestamibi Positive Vs Negative Scan in Primary Hyperparathyroidism; A clinical Dilemma. Bangladesh Journal of Nuclear Medicine 2014 vol.1; 142-145.

5. Sager S, Shafipour H, Asa S, Y1lmaz S, Teksöz S and ÖnselC. Comparison of Tc-99m pertechnetate images with dual-phase Tc $99 \mathrm{~m}$ MIBI and SPECT images in primary hyperparathyroid. Indian J

EndocrinolMetab. 2014 Jul-Aug; 18(4): 531-536. Doi:10.4103/2230-8210.137520.

6. Ishibashi M, Nishida H, Hiromatsu Y, Kojima K, Tabuchi E and Hayabuchi N. Comparison of Technetium-99m-MIBI, Technetium99mTetrofosmin, Ultrasound and MRI for Localization of Abnormal Parathyroid Glands. JNM 1998 Feb;39(2):320-4.

7. Akter M, Begum SMF, Sultana S and Alam F. Primary hyperparathyroidism :Comparison between Tc-99m sestamibi parathyroid scintigraphy, Neck Ulrasonography and their correlation with serum calcium, parathyroid hormone levels. BJNM 2013 July; vol.1;no.2;116-122.

8. Hoang T, JaniA, Mai W, Tuamokumo F and Shakir M. Association of Serum Ionized Calcium, Phosphate and PTH levels with Technetium

-99m Sestamibi Parathyroid SPECT/CT scan in primary hyperparathyroidism. Endocrine practice 2018. Doi:10.4159/EP-2018-0414.

9. Nasreen F, Ahsan ASMA, Yasmeen,S and Kabir MF. A prospective evaluation of preoperative localization of abnormal parathyroid gland by Tc-99m sestamibi scintigraphy and ultrasonography in primary hyperthyroidism, BJNM 2007.vol.10,no.2;112-116.

10. Nasiri S, Soroush A, Hashemi AP, Hedayat A, Donboli K, and Mehrkhani. Parahtyroid adenoma localization. Medical journal of Islamic republic of Iran $2012 ; 26(3): 103-9$.

11. Ebner Y, Garti-Gross Y, Margulis A, Levy Y, Nabrisky D, Ophor D, Rotman-Pikielny P. Paratyroid surgery:correlation between preoperative localization studies and surgical outcomes. Clin Endocrinol (Oxf).2015;83(5);733-738.Doi:10.1111/cen.12835 